\title{
Optimasi Waktu Sandar Kapal Untuk Meningkatkan Kinerja Pelayanan Di Terminal Jamrud Pelabuhan Tanjung Perak Surabaya
}

\author{
Amilia Lalita Ivana ${ }^{1)}$, Hary Moetriono ${ }^{2) *}$ \\ 1) 2) Fakultas Teknik, Program Studi Teknik Sipil, Universitas 17 Agustus 1945 Surabaya, Jl. Semolowaru \\ No.45, Menur Pumpungan, Kec. Sukolilo, Kota SBY, Jawa Timur. Email: amiliaivana@gmail.com, \\ nono.harmoet@gmail.com
}

\begin{abstract}
Abstrak
Transportasi laut merupakan sarana penting diberbagai bidang, antara lain adalah bidang ekonomi, sosial, keamanan, dan lain-lain. Prasarana paling penting dalam keberlangsungan transportasi laut adalah pelabuhan. Terminal Jamrud Pelabuhan Tanjung Perak merupakan terminal barang yang melayani domestik dan internasional. Dalam menjaga pelayanan pelabuhan agar berjalan tetap optimal, maka perlu menghindari waktu tunggu kapal. Penelitian ini bertujuan untuk membuat strategi optimasi waktu sandar kapal dengan mengoptimalkan pelayanan pengangkutan. Penelitian ini dilakukan dengan mengumpulkan dan mengevaluasi data bongkar muat selama 6 tahun terakhir (tahun 2011 sampai 2017). Analisa pelayanan di terminal Jamrud pelabuhan Tanjung Perak dilakukan dengan menggunakan metode pemrograman linier dan model metode model antrian. Hasil output yang utama adalah optimasi waktu sandar kapal. Hasil hasil analisis deskriptif kuantitatif dengan tujuan untuk meminimalkan waktu sandar kapal mendapatkan solusi yaitu dengan penambahan $50 \%$ NOT (Not Operation Time), $75 \%$ NOT (Not Operation Time), dan 100\% NOT (Not Operation Time) pada ET (Efektif Time), maka efektivitas untuk semua jenis muatan di semua dermaga di Terminal Jamrud sesuai dengan SOP yaitu 70\%. Dan juga dengan penambahan 50\% IT (Idle Time) dan 50\% NOT (Not Operation Time) pada ET (Efektif Time), penambahan $75 \%$ IT (Idle Time) dan $75 \%$ NOT (Not Operation Time) pada ET (Efektif Time) dan penambahan $100 \%$ IT (Idle Time) dan 100\% NOT (Not Operation Time) pada ET (Efektif Time) efektivitas sudah sesuai dengan SOP yaitu $70 \%$
\end{abstract}

Kata kunci: Optimasi waktu, Idle Time, Not Operation Time.

\begin{abstract}
Sea transportation is an important tool in various fields, including the economic, social, security, and others. The most important infrastructure in the sustainability of sea transportation is the port. Terminal Jamrud Tanjung Perak Port is a terminal of goods serving both domestic and international. In keeping the port service to run optimally, it is necessary to avoid waiting time for ships. This research aims to make optimization strategy of boat dock time by optimizing transportation service. This research was conducted by collecting and evaluating data of loading and unloading during the last 6 years (2011 to 2017). Analysis of service at Jamrud terminal Tanjung Perak port is done by using linear programming method and model model queue model. The main output is the optimization of the dock time. The result of quantitative descriptive analysis with the aim to minimize the dock time to get solution that is by the addition of 50\% NOT (Not Operation Time), 75\% NOT (Not Operation Time), and $100 \%$ NOT (Operation Time) on ET (Effective Time), then the effectiveness for all types of cargo at all docks at Terminal Emeralds in accordance with SOP is 70\%. And also with the addition of 50\% IT (Idle Time) and 50\% NOT (Operating Time) on ET (Effective Time), 75\% IT (Idle Time) and 75\% NOT (Operating Time) ET (Effective Time) and the addition of 100\% IT (Idle Time) and 100\% NOT (Not Operation Time) on ET (Effective Time) effectiveness is in accordance with SOP that is $70 \%$.
\end{abstract}

Keywords: Time optimization, Idle Time, Not Operation Time.

\section{PENDAHULUAN}

Indonesia merupakan negara maritim, yaitu negara yang berada dalam wilayah teritorial laut yang sangat luas. Negara maritim sangat erat kaitannya dengan pelayaran, pelayaran sendiri memiliki peran penting dalam bidang sosial, ekonomi, pertahanan/keamanan, dan sebagainya. Bidang kegiatan pelayaran dapat dibedakan menjadi dua yaitu pelayaran niaga dan bukan niaga.

Selain negara maritim, Indonesia juga merupakan negara kepulauan, dengan jumlah pulau lebih dari 17.000 pulau dan total luas wilayah Indonesia adalah 2.001.648,97 km2. Luas daratan $1.904 .569 \mathrm{~km}^{2}$, sedangkan luas 
wilayah laut adalah $96.079,15 \mathrm{~km}^{2}$. Dengan sangat luasnya wilayah Indonesia kegiatan angkutan penumpang ataupun barang, menjadi sangat penting untuk menghubungkan antar pulau, maka dari itu membutuhkan pelabuhan.

Pelabuhan (port) adalah daerah perairan yang terlindungi terhadap gelombang, yang dilengkapi dengan fasilitas terminal laut meliputi dermaga di mana kapal dapat bertambat untuk bongkar muat barang, krankran (crane) untuk bongkar muat barang, gudang laut (transito) dan tempat-tempat penyimpanan dimana kapal membongkar muatannya, dan gudang-gudang di mana barang-barang dapat disimpan dalam waktu yang lebih lama selama menunggu pengiriman ke daerah tujuan atau pengapalan. (Triatmodjo, 2010).

Dermaga adalah bangunan pelabuhan yang digunakan untuk merapatnya kapal dan menambatkannya pada waktu bongkar muat barang. Pada pelabuhan barang, dibelakang dermaga harus terdapat halaman yang cukup luas untuk menempatkan barang-barang selama menunggu pengapalan atau angkutan ke darat. Dermaga juga dilengkapi dengam kran atau alat bongkar-muat lainnya untuk mengangkut barang dari kapal ke kapal (Triatmodjo, 2010).

Pelabuhan Tanjung perak merupakan pelabuhan yang terletak di Provinsi Jawa Timur, secara administratif Pelabuhan Tanjung Perak termasuk ke dalam Kelurahan Perak Timur, Kecamatan Pabean Cantikan, Kota Surabaya. Terdapat enam terminal di Pelabuhan Tanjung Perak, yakni, Jamrud Nilam, Mirah, Kalimas, Berlian, dan Petikemas (Ahmad, 2016). Terminal jamrud merupakan terminal yang melayani baik domestik maupun internasional. Di Terminal Jamrud melayani jenis muatan general cargo, bag cargo, curah cair, curah kering (dry bulk), kinerja unitized, dan peti kemas. Terminal Jamrud memiliki tiga dermaga yang digunakan untuk sandar atau tambat kapal, antara lain adalah dermaga utara kapal internasional sedangkan dermaga barat dan selatan untuk kapal domestik.

Fluktuasi angkutan yang terjadi pada lintas penyeberangan sangat berpengaruh pada selang waktu keberangkatan, jumlah dan kapasitas muat kapal (Andriani, 2011). Pemenuhan harapan pengguna jasa angkutan penyeberangan terhadap kualitas pelayanan merupakan hal penting bagi organisasi jasa untuk menghadapi persaingan bisnis. Kualitas pelayanan di nilai dengan atribut jasa meliputi, kenyamanan, keamanan, keselamatan, ketepatan waktu, tarif untuk melihat standar minimum pelayanan yang ada dan waktu pelayanan minimum.

Dalam pelayanannya, apabila kemungkinan terjadi gangguan pengoperasian salah satu dermaga dan kerusakan pada beberapa unit kapal diharapkan sistem penyeberangan tidak terganggu dan masih mampu memberikan pelayanan yang optimal, sehingga antrian (waktu tunggu) penumpang dapat diminimalkan (Suparsa, 2009; Wijaya, 2016).

Terminal Jamrud merupakan salah satu terminal tersibuk yang melayani muatan general cargo, bag cargo,curah kering, curah cair, unitized dan peti kemas yang melayani domestik maupun internasional. Masalah kinerja pelayanan sering dijumpai dalam operasional pelabuhan, begitu juga dengan Terminal Jamrud. Kurangnya efektivitas dan produktivitas dalam bongkar muat adalah salah satu akibat kurang tepatnya manajemen pengoperasian pelabuhan. Salah satu parameter yang perlu diperhatikan dalam upaya peningkatan pelayanan adalah lamanya waktu efektif yang dibutuhkan suatu kapal untuk melakukan bongkar muat barang serta produktivitas bongkar muat barang di dermaga.

Tujuan penelitian ini adalah untuk mengatahui penyebab pelayanan pengangkutan tidak berjalan dengan optimal di terminal Jamrud. Selanjutnya dicari juga cara mengatasi pelayanan pengangkutan dengan mengoptimasi waktu sandar kapal sehingga dapat mengoptimasi waktu sandar kapal dan dapat mengoptimalkan kapasitas angkut

\section{METODE}

Penelitian ini mengikuti diagram alir penelitian seperti tampak pada Gambar 1.

Menurut Sudjiono (1987) analisis kuantitatif dalam suatu penelitian dapat didekati dari dua sudut pendekatan, yaitu analisis kuantitatif secara deskriptif, dan analisis kuantitatif secara inferensial. Menurut Arikunto (1993) mengenai data dengan statistik deskriptif peneliti perlu memperhatikan terlebih dahulu jenis datanya. Jika peneliti mempunyai data diskrit, penyajian data yang dapat dilakukan adalah mencari frekuensi mutlak, frekuensi relative. 


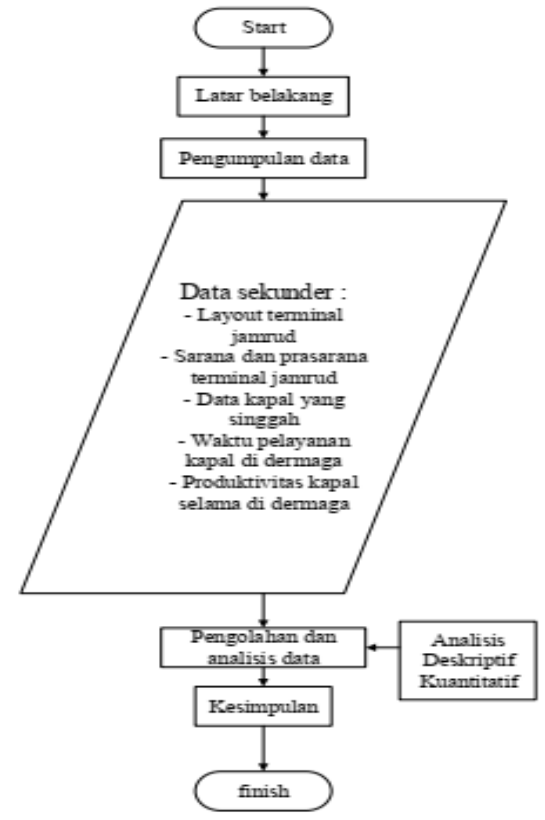

Gambar 1. Diagram Alir Penalitian

\section{Teknik Pengumpulan Data}

Pengumpulan data sekunder dilakukan dengan cara mengkaji data penelitian terdahulu dan meminta data kepada PT. Pelindo III, seperti layout pelabuhan, sarana prasarana, dan formasi kapal

\section{Kebutuhan Data Sekunder}

Data sekunder yang dibutuhkan dalam penelitian ini sebagai berikut :

a. Layout terminal Jamrud Pelabuhan Perak Surabaya

b. Sarana dan prasarana Jamrud Pelabuhan Perak Surabaya

c. Data jumlah kapal yang singgah

d. Waktu pelayanan kapal di dermaga.

e. Produktivitas kapal selama di dermaga

\section{HASIL DAN PEMBAHASAN}

\section{Waktu Pelayanan Kapal di Dermaga}

Waktu pelayanan kapal di dermaga akan berkaitan dengan banyak hal. Beberapa kondisi yang dapat diteliti antara lain BT (Berth Time) yaitu waktu tambak sejak ikat tali sampai dengan lepas tali, BWT (Berth Working Time) yaitu waktu kapal mulai kerja sampai dengan kapal selesai kerja, IT (Idle Time) yaitu waktu tidak efektif atau tidak produktif atau terbuang selama kapal berada di tambatan disebabkan pengaruh cuaca dan peralatan bongkar muat yang rusak, NOT (Not Operation Time) yaitu waktu jeda, waktu berhenti, yang direncanakan selama kapal di pelabuhan (persiapan bongkar muat dan istirahat kerja), ET (Efektif Time) yaitu jumlah waktu efektif yang digunakan untuk melakukan kegiatan bongkar muat selama kapal di tambatan. Secara lengkap waktu pelayanan kapal di dermaga Jamrud seperti tampak pada Tabel 1 .

Tabel 1. Waktu Pelayanan Kapal di Dermaga

\begin{tabular}{|c|c|c|c|c|c|c|}
\hline \multirow{2}{*}{$\begin{array}{l}\text { Nama } \\
\text { Derma } \\
\text { ga }\end{array}$} & \multirow[t]{2}{*}{ Muatan } & \multicolumn{5}{|c|}{ Waktu Pelayanan } \\
\hline & & BT & $\begin{array}{l}\mathrm{BW} \\
\mathrm{T} \\
\end{array}$ & IT & $\begin{array}{l}\text { NO } \\
\mathrm{T} \\
\end{array}$ & ET \\
\hline \multirow{6}{*}{$\begin{array}{c}\text { Jamrud } \\
\text { Utara }\end{array}$} & $\begin{array}{l}\text { general } \\
\text { cargo }\end{array}$ & 48 & 48 & 16 & 0 & 32 \\
\hline & bag cargo & $\begin{array}{r}207, \\
7 \\
\end{array}$ & $\begin{array}{r}173, \\
9 \\
\end{array}$ & $\begin{array}{r}47, \\
7\end{array}$ & 33,7 & $\begin{array}{r}126, \\
2 \\
\end{array}$ \\
\hline & $\begin{array}{l}\text { curah } \\
\text { kering }\end{array}$ & 91 & 74 & 16 & 17 & 58 \\
\hline & curah cair & 75 & 60 & 8 & 15 & 52 \\
\hline & unitized & 68 & 63 & 12 & 5 & 51 \\
\hline & peti kemas & 3 & 1 & 0 & 2 & 1 \\
\hline \multirow{2}{*}{$\begin{array}{c}\text { Jamrud } \\
\text { Barat }\end{array}$} & $\begin{array}{l}\text { general } \\
\text { cargo }\end{array}$ & 37 & 28 & 5 & 9 & 23 \\
\hline & curah cair & 43 & 34 & 1 & 9 & 33 \\
\hline \multirow{4}{*}{$\begin{array}{l}\text { Jamrud } \\
\text { Selatan }\end{array}$} & bag cargo & $\begin{array}{r}125, \\
1 \\
\end{array}$ & $\begin{array}{r}107, \\
1 \\
\end{array}$ & $\begin{array}{r}22, \\
8 \\
\end{array}$ & $\begin{array}{r}17,9 \\
8 \\
\end{array}$ & 84,2 \\
\hline & $\begin{array}{l}\text { curah } \\
\text { kering }\end{array}$ & 68 & 54 & 17 & 14 & 37 \\
\hline & unitized & 30 & 19 & 1 & 11 & 18 \\
\hline & peti kemas & 29 & 21 & 4 & 8 & 17 \\
\hline
\end{tabular}

\section{Total Muatan Kapal di Dermaga}

Total muatan kapal di dermaga Jamrud untuk masing-masing jenis muatan terlihat pada Tabel 2.

Tabel 2. Total Muatan Kapal di Dermaga

\begin{tabular}{ccc}
\hline \multirow{2}{*}{$\begin{array}{c}\text { Nama } \\
\text { Dermaga }\end{array}$} & Muatan & Total Muatan (ton) \\
\hline & General Cargo & 237,578 \\
\cline { 2 - 3 } Jamrud & Bag Cargo & 145,946 \\
\cline { 2 - 3 } Utara & Curah Kering & 432,383 \\
\cline { 2 - 3 } & Curah Cair & 29,968 \\
\cline { 2 - 3 } & Unitized & 13,539 \\
\hline \multirow{2}{*}{$\begin{array}{c}\text { Jamrud } \\
\text { Barat }\end{array}$} & Peti Kemas & 35 \\
\cline { 2 - 3 } & Curah Cair & 93,792 \\
\hline \multirow{2}{*}{$\begin{array}{c}\text { Jamrud } \\
\text { Selatan }\end{array}$} & Bag Cargo & 18,274 \\
\cline { 2 - 3 } & Curah Kering & 28,108 \\
\cline { 2 - 3 } & Unitized & 63,783 \\
\hline
\end{tabular}




\section{Standart Operasional Efektivitas dan Produktivitas Kapal di Dermaga}

Standart operasional efektivitas dan produktivitas kapal di dermaga Jamrud seperti pada Tabel 3.

Tabel 3. Standart Operasional Efektivitas Dan Produktivitas Kapal Di Dermaga

\begin{tabular}{cccc}
\hline \multirow{2}{*}{$\begin{array}{c}\text { Nama } \\
\text { Dermaga }\end{array}$} & Jenis Muatan & \multicolumn{2}{c}{ SOP } \\
\cline { 2 - 4 } & & Efektivitas & Produktivitas \\
\hline & General Cargo & $70 \%$ & $50 \mathrm{~T} / \mathrm{G} / \mathrm{J}$ \\
\cline { 2 - 4 } & Bag Cargo & $70 \%$ & $40 \mathrm{~T} / \mathrm{G} / \mathrm{J}$ \\
\cline { 2 - 4 } $\begin{array}{c}\text { Jamrud } \\
\text { Utara }\end{array}$ & Curah Kering & $70 \%$ & $125 \mathrm{~T} / \mathrm{G} / \mathrm{J}$ \\
\cline { 2 - 4 } & Curah Cair & $70 \%$ & $125 \mathrm{~T} / \mathrm{G} / \mathrm{J}$ \\
\cline { 2 - 4 } & Unitized & $70 \%$ & $75 \mathrm{~T} / \mathrm{G} / \mathrm{J}$ \\
\cline { 2 - 4 } & Peti Kemas & $70 \%$ & $10 \mathrm{~B} / \mathrm{C} / \mathrm{H}$ \\
\hline \multirow{2}{*}{$\begin{array}{c}\text { Jamrud } \\
\text { Barat }\end{array}$} & General Cargo & $70 \%$ & $50 \mathrm{~T} / \mathrm{G} / \mathrm{J}$ \\
\cline { 2 - 4 } & Curah Cair & $70 \%$ & $125 \mathrm{~T} / \mathrm{G} / \mathrm{J}$ \\
\hline \multirow{3}{*}{$\begin{array}{c}\text { Jamrud } \\
\text { Selatan }\end{array}$} & Bag Cargo & $70 \%$ & $40 \mathrm{~T} / \mathrm{G} / \mathrm{J}$ \\
\cline { 2 - 4 } & Curah Kering & $70 \%$ & $125 \mathrm{~T} / \mathrm{G} / \mathrm{J}$ \\
\cline { 2 - 4 } & Unitized & $70 \%$ & $75 \mathrm{~T} / \mathrm{G} / \mathrm{J}$ \\
\cline { 2 - 4 } & Peti Kemas & $70 \%$ & $10 \mathrm{~B} / \mathrm{C} / \mathrm{H}$ \\
\hline
\end{tabular}

Efektivitas dan Produktivitas Kapal di Dermaga

Efektivitas dan produktivitas kapal di dermaga Jamrud seperti pada Tabel 4. Warna merah menandakan Efektivitas tidak tercapai.

Tabel 4. Efektivitas Dan Produktivitas Kapal di Dermaga

\begin{tabular}{cccc}
\hline \multirow{2}{*}{$\begin{array}{c}\text { Nama } \\
\text { Dermaga }\end{array}$} & Muatan & Efektivitas & Produktivitas \\
\cline { 3 - 4 } & & BT:ET & T/G/J \\
\hline \multirow{2}{*}{$\begin{array}{c}\text { Jamrud } \\
\text { Utara }\end{array}$} & Beneral Cargo & 66,67 & 148,49 \\
\cline { 2 - 4 } & Curah Kering & 63,74 & 186,37 \\
\cline { 2 - 4 } & Curah Cair & 69,33 & 288,15 \\
\cline { 2 - 4 } & Unitized & 75 & 265,47 \\
\cline { 2 - 4 } & Peti Kemas & 33,33 & 35 \\
\hline \multirow{2}{*}{$\begin{array}{c}\text { Jamrud } \\
\text { Barat }\end{array}$} & General Cargo & 62,16 & 81,56 \\
\cline { 2 - 4 } & Curah Cair & 76,74 & 184,59 \\
\hline \multirow{2}{*}{$\begin{array}{c}\text { Jamrud } \\
\text { Selatan }\end{array}$} & Bag Cargo & 67,36 & 66,7 \\
\cline { 2 - 4 } & Curah Kering & 54,41 & 246,27 \\
\cline { 2 - 4 } & Unitized & 60 & 299,94 \\
\cline { 2 - 4 } & Peti Kemas & 58,62 & 20,58 \\
\hline
\end{tabular}

Selanjutnya dilakukan upaya optimasi waktu sandar kapal dengan menambahkan IT (Idle Time) diharapkan dapat memenuhi SOP (Standart Operasional Pelayanan) yang ada di Terminal Jamrud Pelabuhan Tanjung Perak Surabaya. Secara lengkap seperti pada Tabel 5.

Tabel 5. Upaya Optimasi dengan Penambahan Idle Time (IT) pada Efektif Time

\begin{tabular}{|c|c|c|c|c|c|c|c|c|c|}
\hline \multirow[b]{2}{*}{$\begin{array}{c}\text { Derm } \\
\text { aga }\end{array}$} & \multirow[b]{2}{*}{ Muatan } & \multicolumn{2}{|c|}{ Upaya Optimasi 25\% IT } & \multicolumn{2}{|c|}{ Upaya Optimasi 50\% IT } & \multicolumn{2}{|c|}{ Upaya Optimasi 75\% IT } & \multicolumn{2}{|c|}{ Upaya Optimasi $100 \%$ IT } \\
\hline & & $\begin{array}{c}\text { Efektivit } \\
\text { as }(\%)\end{array}$ & $\begin{array}{c}\text { Produktivitas } \\
(\mathrm{T} / \mathrm{G} / \mathrm{J})\end{array}$ & $\begin{array}{c}\text { Efektivit } \\
\text { as }(\%)\end{array}$ & $\begin{array}{c}\text { Produktivitas } \\
(\mathrm{T} / \mathrm{G} / \mathrm{J})\end{array}$ & $\begin{array}{c}\text { Efektivit } \\
\text { as (\%) }\end{array}$ & $\begin{array}{c}\text { Produktivitas } \\
(\mathrm{T} / \mathrm{G} / \mathrm{J})\end{array}$ & $\begin{array}{c}\text { Efektivit } \\
\text { as (\%) }\end{array}$ & $\begin{array}{c}\text { Produktivitas } \\
(\mathrm{T} / \mathrm{G} / \mathrm{J})\end{array}$ \\
\hline \multirow{6}{*}{$\begin{array}{l}\text { Jamr } \\
\text { ud } \\
\text { Utara }\end{array}$} & $\begin{array}{c}\text { General } \\
\text { Cargo }\end{array}$ & $75 \%$ & 131,98 & $83,33 \%$ & 118,78 & $91,66 \%$ & 107,99 & $100 \%$ & 98,99 \\
\hline & $\begin{array}{c}\text { Bag } \\
\text { Cargo }\end{array}$ & $66,5 \%$ & 132,04 & $72,25 \%$ & 121,54 & $76,84 \%$ & 112,59 & $83,72 \%$ & 52,25 \\
\hline & $\begin{array}{l}\text { Curah } \\
\text { Kering }\end{array}$ & $68,13 \%$ & 174,34 & $72,53 \%$ & 163,78 & $76,92 \%$ & 154,42 & $82,22 \%$ & 146 \\
\hline & $\begin{array}{l}\text { Curah } \\
\text { Cair }\end{array}$ & $72 \%$ & 277,48 & $74,66 \%$ & 267,57 & $77,33 \%$ & 258,34 & $81 \%$ & 249,73 \\
\hline & Unitized & $79,41 \%$ & 250,72 & $83,82 \%$ & 237,52 & $88,23 \%$ & 225,65 & $93 \%$ & 107,45 \\
\hline & $\begin{array}{c}\text { Peti } \\
\text { Kemas }\end{array}$ & - & - & - & - & - & - & - & - \\
\hline \multirow{2}{*}{$\begin{array}{c}\text { Jamr } \\
\text { ud } \\
\text { Barat }\end{array}$} & $\begin{array}{c}\text { General } \\
\text { Cargo }\end{array}$ & $65,54 \%$ & 77,35 & $68,91 \%$ & 73,56 & $72,29 \%$ & 70,12 & $75,6 \%$ & 67 \\
\hline & $\begin{array}{l}\text { Curah } \\
\text { Cair }\end{array}$ & $77,32 \%$ & 183,19 & $77,90 \%$ & 181,83 & $78,48 \%$ & 180,48 & $79 \%$ & 179,2 \\
\hline \multirow{4}{*}{$\begin{array}{c}\text { Jamr } \\
\text { ud } \\
\text { Selat } \\
\text { an }\end{array}$} & $\begin{array}{c}\text { Bag } \\
\text { Cargo }\end{array}$ & $71,92 \%$ & 62,46 & $76,49 \%$ & 58,73 & $81,06 \%$ & 55,42 & $86 \%$ & 52,47 \\
\hline & $\begin{array}{l}\text { Curah } \\
\text { Kering }\end{array}$ & $60,66 \%$ & 220,89 & $66,91 \%$ & 200,26 & $73,16 \%$ & 183,15 & $79,4 \%$ & 168,74 \\
\hline & Unitized & 60,83 & 295,83 & $61,66 \%$ & 291,83 & $62,5 \%$ & 287,94 & $63 \%$ & 284,16 \\
\hline & $\begin{array}{c}\text { Peti } \\
\text { Kemas }\end{array}$ & $62,06 \%$ & 19,44 & $65,51 \%$ & 18,41 & $68,96 \%$ & 17,49 & $72,4 \%$ & 16,66 \\
\hline
\end{tabular}

Dilakukan pula Upaya Optimasi dengan Penambahan Not Operation Time pada Efektif Time dan Upaya Optimasi dengan Penambahan
Idle Time dan Not Operation Time pada Efektif Time di Dermaga Jamrud Barat 
Tabel 6. Upaya Optimasi dengan Penambahan Not Operation Time pada Efektif Time

\begin{tabular}{|c|c|c|c|c|c|c|c|c|c|}
\hline \multirow{2}{*}{$\begin{array}{c}\text { Nam } \\
\text { a } \\
\text { Derm } \\
\text { aga } \\
\end{array}$} & \multirow{2}{*}{ Muatan } & \multicolumn{2}{|c|}{$\begin{array}{c}\text { Upaya Optimasi 25\% Not } \\
\text { Operation Time }\end{array}$} & \multicolumn{2}{|c|}{$\begin{array}{c}\text { Upaya Optimasi } 50 \% \text { Not } \\
\text { Operation Time }\end{array}$} & \multicolumn{2}{|c|}{$\begin{array}{c}\text { Upaya Optimasi } 75 \% \text { Not } \\
\text { Operation Time }\end{array}$} & \multicolumn{2}{|c|}{$\begin{array}{l}\text { Upaya Optimasi } 100 \% \\
\text { Not Operation Time }\end{array}$} \\
\hline & & $\begin{array}{c}\text { Efektivit } \\
\text { as (\%) }\end{array}$ & $\begin{array}{c}\text { Produktivitas } \\
(\mathrm{T} / \mathrm{G} / \mathrm{J})\end{array}$ & $\begin{array}{c}\text { Efektivit } \\
\text { as (\%) }\end{array}$ & $\begin{array}{c}\text { Produktivitas } \\
(\mathrm{T} / \mathrm{G} / \mathrm{J})\end{array}$ & $\begin{array}{c}\text { Efektivit } \\
\text { as (\%) }\end{array}$ & $\begin{array}{c}\text { Produktivitas } \\
(\mathrm{T} / \mathrm{G} / \mathrm{J})\end{array}$ & $\begin{array}{l}\text { Efektivit } \\
\text { as }(\%)\end{array}$ & $\begin{array}{c}\text { Produktivitas } \\
(\mathrm{T} / \mathrm{G} / \mathrm{J})\end{array}$ \\
\hline \multirow{6}{*}{$\begin{array}{l}\text { Jamr } \\
\text { ud } \\
\text { Utara }\end{array}$} & $\begin{array}{c}\text { General } \\
\text { Cargo }\end{array}$ & - & - & - & - & - & - & - & $\begin{array}{lll}- & - \\
-1\end{array}$ \\
\hline & $\begin{array}{c}\text { Bag } \\
\text { Cargo }\end{array}$ & $64,82 \%$ & 135,45 & $68,89 \%$ & 127,46 & $72,96 \%$ & 120,35 & $77 \%$ & 57 \\
\hline & $\begin{array}{l}\text { Curah } \\
\text { Kering } \\
\end{array}$ & $68,40 \%$ & 173,64 & $73,07 \%$ & 162,55 & $77,74 \%$ & 152,78 & $83,33 \%$ & 144 \\
\hline & $\begin{array}{l}\text { Curah } \\
\text { Cair }\end{array}$ & $74,33 \%$ & 268,77 & $79,33 \%$ & 251,83 & $84,33 \%$ & 236,90 & $90,5 \%$ & 223,64 \\
\hline & Unitized & $76,83 \%$ & 259,11 & $78,67 \%$ & 253,06 & $80,51 \%$ & 247,28 & $82,4 \%$ & 120,88 \\
\hline & $\begin{array}{c}\text { Peti } \\
\text { Kemas } \\
\end{array}$ & $50 \%$ & 23,33 & $66,66 \%$ & 17,5 & $83,33 \%$ & 14 & $100 \%$ & 11,66 \\
\hline \multirow{2}{*}{$\begin{array}{c}\text { Jamr } \\
\text { ud } \\
\text { Barat }\end{array}$} & $\begin{array}{c}\text { General } \\
\text { Cargo }\end{array}$ & $68,24 \%$ & 74,29 & $74,32 \%$ & 68,21 & $80,40 \%$ & 63,05 & $86 \%$ & 86,62 \\
\hline & $\begin{array}{l}\text { Curah } \\
\text { Cair }\end{array}$ & $81,97 \%$ & 172,80 & $87,20 \%$ & 162,43 & $92,44 \%$ & 153,24 & $98 \%$ & 145 \\
\hline \multirow{4}{*}{$\begin{array}{c}\text { Jamr } \\
\text { ud } \\
\text { Selat } \\
\text { an }\end{array}$} & $\begin{array}{c}\text { Bag } \\
\text { Cargo } \\
\end{array}$ & $70,95 \%$ & 63,32 & $74,54 \%$ & 60,27 & $78,13 \%$ & 57,50 & $82 \%$ & 54,97 \\
\hline & $\begin{array}{l}\text { Curah } \\
\text { Kering }\end{array}$ & $59,55 \%$ & 224,98 & $64,70 \%$ & 207,08 & $69,85 \%$ & 191,82 & $75 \%$ & 178,66 \\
\hline & Unitized & $69,16 \%$ & 260,19 & $78,33 \%$ & 229,74 & $87,5 \%$ & 205,67 & $96 \%$ & 186,17 \\
\hline & $\begin{array}{c}\text { Peti } \\
\text { Kemas } \\
\end{array}$ & $65,51 \%$ & 18,41 & $72,41 \%$ & 16,66 & $79,31 \%$ & 15,21 & $86,2 \%$ & 14 \\
\hline
\end{tabular}

Tabel 7. Upaya Optimasi dengan Penambahan Idle Time dan Not Operation Time pada Efektif Time di Dermaga Jamrud Barat

\begin{tabular}{|c|c|c|c|c|c|c|c|c|c|}
\hline \multirow{2}{*}{$\begin{array}{c}\text { Nam } \\
\text { a } \\
\text { Derm } \\
\text { aga }\end{array}$} & \multirow{2}{*}{ Muatan } & \multicolumn{2}{|c|}{$\begin{array}{c}\text { Upaya Optimasi 25\% IT } \\
\text { dan 25\% NOT }\end{array}$} & \multicolumn{2}{|c|}{$\begin{array}{c}\text { Upaya Optimasi 50\% IT } \\
\text { dan 50\% NOT }\end{array}$} & \multicolumn{2}{|c|}{$\begin{array}{c}\text { Upaya Optimasi } 75 \% \text { IT } \\
\text { dan } 75 \% \text { NOT }\end{array}$} & \multicolumn{2}{|c|}{$\begin{array}{c}\text { Upaya Optimasi } 100 \% \text { IT } \\
\text { dan } 100 \% \text { NOT }\end{array}$} \\
\hline & & $\begin{array}{l}\text { Efektivit } \\
\text { as (\%) }\end{array}$ & $\begin{array}{c}\text { Produktivitas } \\
(\mathrm{T} / \mathrm{G} / \mathrm{J})\end{array}$ & $\begin{array}{l}\text { Efektivit } \\
\text { as (\%) }\end{array}$ & $\begin{array}{c}\text { Produktivitas } \\
(\mathrm{T} / \mathrm{G} / \mathrm{J})\end{array}$ & $\begin{array}{c}\text { Efektivit } \\
\text { as }(\%)\end{array}$ & $\begin{array}{c}\text { Produktivitas } \\
(\mathrm{T} / \mathrm{G} / \mathrm{J})\end{array}$ & $\begin{array}{c}\text { Efektivit } \\
\text { as (\%) }\end{array}$ & $\begin{array}{c}\text { Produktivitas } \\
(\mathrm{T} / \mathrm{G} / \mathrm{J})\end{array}$ \\
\hline \multirow{6}{*}{$\begin{array}{c}\text { Jamr } \\
\text { ud } \\
\text { Utara }\end{array}$} & $\begin{array}{c}\text { General } \\
\text { Cargo }\end{array}$ & - & - & - & - & - & - & - & - \\
\hline & $\begin{array}{l}\text { Bag } \\
\text { Cargo }\end{array}$ & $70,57 \%$ & 124,43 & $80,38 \%$ & 109,25 & $90,19 \%$ & 97,36 & $100 \%$ & 43,92 \\
\hline & $\begin{array}{l}\text { Curah } \\
\text { Kering } \\
\end{array}$ & $72,80 \%$ & 163,16 & 81,86 & 145,09 & $90,93 \%$ & 130,62 & $100 \%$ & 128 \\
\hline & $\begin{array}{l}\text { Curah } \\
\text { Cair }\end{array}$ & $77 \%$ & 259,46 & $84,66 \%$ & 235,96 & $92,33 \%$ & 216,37 & $100 \%$ & 199,8 \\
\hline & Unitized & $81,25 \%$ & 245,04 & $87,5 \%$ & 227,54 & $93,75 \%$ & 212,37 & $100 \%$ & 99,55 \\
\hline & $\begin{array}{c}\text { Peti } \\
\text { Kemas } \\
\end{array}$ & - & - & - & - & - & - & - & - \\
\hline \multirow{2}{*}{$\begin{array}{c}\text { Jamr } \\
\text { ud } \\
\text { Barat }\end{array}$} & $\begin{array}{c}\text { General } \\
\text { Cargo }\end{array}$ & $71,62 \%$ & 70,78 & $81,08 \%$ & 62,52 & $90,54 \%$ & 55,99 & $100 \%$ & 50,7 \\
\hline & $\begin{array}{c}\text { Curah } \\
\text { Cair }\end{array}$ & $82,55 \%$ & 171,58 & $88,37 \%$ & 160,29 & $94,18 \%$ & 150,40 & $100 \%$ & 141,7 \\
\hline \multirow{4}{*}{$\begin{array}{c}\text { Jamr } \\
\text { ud } \\
\text { Selat } \\
\text { an }\end{array}$} & $\begin{array}{l}\text { Bag } \\
\text { Cargo } \\
\end{array}$ & $75,51 \%$ & 59,49 & $83,67 \%$ & 53,69 & $91,83 \%$ & 48,92 & $100 \%$ & 44,9 \\
\hline & $\begin{array}{l}\text { Curah } \\
\text { Kering }\end{array}$ & $65,80 \%$ & 203,61 & $77,20 \%$ & 173,55 & $88,60 \%$ & 151,23 & $100 \%$ & 132 \\
\hline & Unitized & $70 \%$ & 257,09 & $80 \%$ & 224,95 & $90 \%$ & 199,96 & $100 \%$ & 179,97 \\
\hline & $\begin{array}{c}\text { Peti } \\
\text { Kemas }\end{array}$ & $68,96 \%$ & 17,49 & $79,31 \%$ & 15,21 & $89,65 \%$ & 13,45 & $100 \%$ & 12 \\
\hline
\end{tabular}

\section{SIMPULAN}

Penyebab pelayanan pengangkutan tidak berjalan dengan optimal adalah adalah disebabkan pengaruh cuaca dan peralatan bongkar muat yang berpengaruh pada Idle Time (IT), serta waktu jeda, waktu berhenti, waktu persiapan bongkar muat dan istirahat kerja yang terlalu lama yang berpengaruh pada Not Operation Time (NOT).

Mengoptimasi waktu sandar kapal agar sesuai dengan SOP (Standart Operasional Pelayanan) yaitu dengan menambahkan IT (Idle Time) pada ET (Efektif Time), dengan panambahan 25\%, $50 \%$ dan $75 \%$ IT (Idle Time) pada ET (Efektif 
Time) maka presentase waktu efektif kurang berjalan optimal yaitu dibawah SOP yang seharusnya $70 \%$.

Dengan penambahan 25\% NOT (Not Operation Time) pada ET (Efektif Time) kurangnya efektivitas terjadi di Dermaga Jamrud Utara pada muatan bag cargo, curah kering, dan peti kemas yaitu sebesar 64,82\%, 68,40\% dan 50\%, di Dermaga Jamrud Barat kurangnya efektivitas dengan penambahan 25\% NOT (Not Operation Time) pada ET (Efektif Time) terjadi pada muatan general cargo yaitu sebesar $68,24 \%$ dan di Dermaga Jamrud selatan kurangnya efektivitas terjadi pada muatan curah kering, unitized dan peti kemas yaitu sebesar 59,55\%, $69,16 \%$ dan $65,51 \%$.

Dengan penambahan 50\% NOT (Not Operation Time) pada ET (Efektif Time) kurangnya efektivitas terjadi di Dermaga Jamrud Utara pada muatan bag cargo dan peti kemas yaitu sebesar 68,89 dan 66,66\% sedangan di Dermaga Jamrud Selatan kurangnya efektivitas dengan penambahan 25\% NOT (Not Operation Time) pada ET (Efektif Time) kurangnya efektivitas terjadi di Dermaga Jamrud Selatan pada muatan curah kering yaitu sebesar $64,7 \%$. Dengan penambahan 50\% NOT (Not Operation Time), 75\% NOT (Not Operation Time), dan $100 \%$ NOT (Not Operation Time) pada ET (Efektif Time) efektivitas untuk semua jenis muatan di semua dermaga di Terminal Jamrud sesuai dengan SOP yaitu $70 \%$.

Penambahan $25 \%$ IT (Idle Time) dan $25 \%$ NOT (Not Operation Time) pada ET (Efektif Time) kurangnya efektivitas terjadi di Dermaga Jamrud Selatan yaitu pada muatan curah kering dan peti kemas yaitu sebesar $65,80 \%$ dan 68,96\%. Penambahan 50\% IT (Idle Time) dan $50 \%$ NOT (Not Operation Time) pada ET (Efektif Time), penambahan 75\% IT (Idle Time) dan $75 \%$ NOT (Not Operation Time) pada ET (Efektif Time) dan penambahan 100\% IT (Idle Time) dan $100 \%$ NOT (Not Operation Time) pada ET (Efektif Time) efektivitas sudah sesuai dengan SOP yaitu 70\%. Produktivitas untuk semua upaya optimasi sudah sesuai dengan SOP.

Dengan Efektif Time (ET) yang lebih lama, maka pengangkutan seharusnya dapat dilakukan dengan semaksimal mungkin.

\section{DAFTAR PUSTAKA}

Ahmad, Aulia., dan Muhammad Mashuri. 2016, Analisis Sistem Antrian Kapal Pengangkut Barang di Pelabuhan Tanjung Perak Surabaya, Jurnal Sains dan Seni ITS, Vol. 5 No.1.

Andriani, Irawati. 2011, Optimalisasi Waktu Sandar Penyebrangan Untuk Meningkatkan Kinerja Pelayanan di Pelabuhan Merak-Bakauheni, Tesis. Progam Transportasi Pascasarjana. Jakarta: Universitas Indonesia.

Arikunto, Suharsimi, 1993, Manajemen Penelitian, Jakarta: Rineka Cipta.

Instruksi Presiden Republik Indonesia No. 5 Tahun 2005 Tentang Asas Cabotage.

Keputusan Menteri Perhubungan Republik Indonesia Nomor : KM. 49 Tahun 2005 Tentang SISTRANAS (Sistem Transportasi Nasional).

Keputusan Menteri Republik Indonesia No.19 Tahun 2006 Tentang Perubahan Atas Peraturan Pemerintah Nomor 62 Tahun 2002 Tentang Tarif Atas Jenis Penerimaan Negara Bukan Pajak yang Berlaku Pada Departemen Kelautan dan Perikanan.

Peraturan bersama Mendag Republik Indonesia dan Menhub Republik Indonesia No. 20/MDAG/4/'06 Tentang Pengangkutan Barang/Muatan Impor Milik Pemerintah Oleh Perusahaan Angkutan Laut Nasional.

Peraturan Pemerintah Republik Indonesia Nomor : 82 Tahun 1999 Tentang Angkutan Perairan.

Sudijono, Anas, 1987, Pengantar Statistik Pendidikan, Jakarta: Rajawali Pers.

Suparsa, I Gusti Putu. 2009, Optimasi Kinerja Pelabuhan Penyeberangan Ketapang Gilimanuk, Jurnak Ilmiah Teknik Sipil Universitas Udayana, Vol. 13, No. 1.

Triatmodjo, Bambang. 2010, Perencanaan Pelabuhan, Beta Offset., Yogyakarta.

Undang-Undang Republik Indonesia No. 17 tahun 2008 Tentang Pelayaran.

Wijaya, Oki Endrata. 2016, Optimasi Tingkat Pelayanan Dermaga Pada Pelabuhan Bakauheni Lampung, Tesis., Program Pascasarjana Teknik Sipil., Lampung : Universitas Lampung. 